The Journal of Society and Media, April 2021, Vol. 5(1) 1-18

https://journal.unesa.ac.id/index.php/jsm/index

E-ISSN 2580-1341 and P-ISSN 2721-0383

Accredited KEMENRISTEK/ BRIN No.148/M/KPT/2020

DOI: 10.26740/jsm.v5n1.p1-18

\title{
Political Dynamics the Rift of EPRDF Coalitions Since the Outbreak of Qerro's Protest to the Nomination of Dr. Abiy Ahmed in Ethiopia
}

\author{
Dame Dereba Shoa ${ }^{1 *}$, Hana Mekonen Gizaw ${ }^{2}$ \\ ${ }^{1,2}$ College of Social Sciences and Humanities, Haramaya University Haramaya, Oromia, \\ Ethiopia \\ Email: damedereba@gmail.com \\ Email: hanisoci19@gmail.com
}

\begin{abstract}
Ethiopia has been under the rule of EPRDF coalitions, a vanguard party ruling the country since the collapse of Derg regime. This article is therefore, intended to explore the political dynamics associated with the rift of EPRDF coalitions since the outbreaks of Qerro's protest. To meet the study purposes, qualitative research design was employed to collect the data. The study reveals that the broke out of Qerro's protest against integrated master plan of Addis Ababa and tyrannical rule of EPRDF used to be the key dawn towards the step down of titular OPDO officials and empowerment of reformist ODP officials in place that eventually split ruling coalitions in to conservative and reformist. Broad spectrum of political dynamics like: declaration of state of emergency, massive displacement of Oromo people from Ethio-Somali region, wider public protests accompanied by sectorial boycotts, political unrest, apprehension of contrabandist, resignation of late prime minister, Mr. Hailemariam Desalegn and nomination of Dr. Abiy Ahmed in place and others were ensued from the rift of ruling coalitions. The study implicate that polarized political interests amidst the ruling parties (TPLF and PP) could be extended to the oppositions and wider people that may escalate ethnic tensions and thereby ensue in the state fragility.
\end{abstract}

Keywords: political, rift, dynamics, protest, coalitions

Paper type: Research paper

*Corresponding author: damedereba@gmail.com

Submited: 2020-02-04; Accepted: 2020-07-22; Published: 2021-04-29

Cite this document: Shoa, Dame Dereba and Hana Mekonen Gizaw. (2021). Political Dynamics the Rift of EPRDF Coalitions Since the Outbreak of Qerro's Protest to the Nomination of Dr. Abiy Ahmed in Ethiopia. The Journal of Society and Media, 5(1), 1-18. DOI: $10.26740 /$ jsm.v5n1.p1-18 


\section{INTRODUCTION}

Ethiopian politics have been undergoing trajectories of reformism and revolution at different times particularly since the country was unified under the rule of Emperor Minilik the second. The country has been under imperial rules until the Derg junta; a military rule took over the power (Lyons 2019). Derg regime, the successor incumbent maintained the unitary state under the overwhelming manifesto of Centralized power exercises, socialism and "Ethiopia Tikdem", which means Ethiopia first, down playing ethnic diversities in the country (Edmond Keller 2002). Failure of unitary state to respond to the recognition of ethnic diversities and social cleavages called for the ensuing advent of ethnic liberation movements in the country. Emergency of ethnic liberation fronts like EPLF (Eritrian people liberation front), TPLF (Tigrai people liberation front), OLF (Oromo liberation front) and multi directional armed protest against the Derg junta speeded up the demise of the hitherto unitary state (Abbink 2006).

Political scenarios that took place after the subjugation of Derg regime was roundtable bargaining between political elites fought against the Derg, on the way forward of Ethiopian politics. Draft of constitutional pact to establish federation and withdrawal of Eritrea from the federation ushered the transition. State structure was rearranged from hitherto unitary state to ethnic federalism that rhetorically materializes the constitutional pact. Thus, transitional government installed federation that encourages devolution of power to regional authorities in order to balance self-rule with shared rule (Abbink 2011). One Scholar, argued that ethnic federalism was alleged to be a middle ground solution for Ethiopia as it embraces ethnic diversities and social cleavages (Edmond Keller 2002). So, federation was meant to "stay together" in order to avoid possible balkanization of the country in the course of nation building. Within this premises, EPRDF (Ethiopian people republic democratic front), a four coalition parties of four ethnic regions got prepared to govern the country since 1991 (Adem 2004). One year later, EPRDF restored the monopoly of political space at the center by relegating the political opponents. De facto federalism was contended with promised devolution of power that was constituted in the transitional pact. Maintaining political hegemony at the center, TPLF led EPRDF tilted its allegiance to one ethnic group and proven its asymmetric representation. Since 1992 Ethiopian ethnic federalism was shifted 


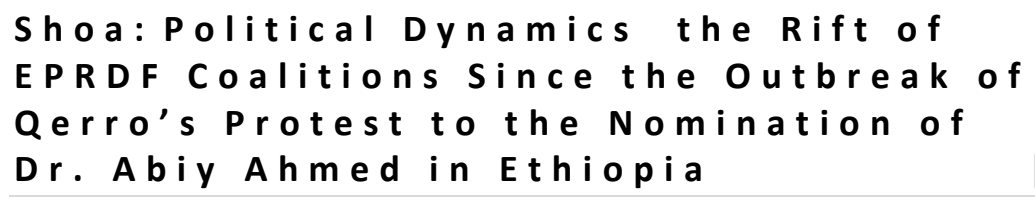

from "staying together" to "putting together" due to the monopolization of political space by the EPRDF (Edmond Keller 2002).

The incumbent regime, EPRDF composes four collided and partner parties ruling the country sharing power among itself though vividly the hegemony of TPLF (Tigrai People's liberation front) has been taken for granted by the factions until the synergy of "Qerro", "Fano", "Zurma" and other movements vanquished its supremacy (Gizaw 2019). Remaining three parties namely: ODP (Oromo Democratic Party), the former OPDO (Oromo people's democratic organization), ADP (Amahara Democratic Party), the former ANDM (Amhara national democratic movement) and SPDM (southern people's democratic movement) have been acting submissively and nominally to the interest of TPLF. Historically, the ultimate goal of these parties were to depose the Derg junta and establish transitional government despite its grip of power for around three decades by banishing the political opponents (Aalen 2006).

Rhetorically, EPRDF was operating under the flagship of democracy, peace, development, unity in diversity and equality despite the fact that citizens have been blaming for the deficit of democracy. EPRDF has also been castigated for corruption, maladministration, political conspiracy among itself for which it openly apologized. Some citizens claim that EPRDF is a bigotry government that monopolized the political space by denying opportunities to the opponents. Members of the opposition parties and political activists have been fleeing from unofficial kidnapping and mysterious undemocratic treatment of EPRDF government in locked up jails. Being a vanguard party, EPRDF won 100 percent of vote by 2015 election which boldly revealed its undemocratic nature (Lyons 2019). Thus, dichotomy of rhetoric democracy and de facto tyranny on the ground resulted in unceasing outbreaks of movements against EPRDF. Though, it was attempted to suppress the protests by deploying polices and reforming cadres at different times the movements continued and finally extended to the ruling party itself. Eventually, the protests gave birth to the rift of four coalition parties into conservatives and reformists. Polarization of the incumbent regime into change seekers on the one side, and statuesque on the other side further augmented the discrepancies amidst the intransigent and the reformist. Rifts accompanied by political conspiracies 
among EPRDF coalitions have shifted to the political rivalries which aggravated the internal challenges beyond the protests countered from dissenters and the wider public. Therefore, the aim of this study was to divulge the rift of EPRDF coalition parties into conservative, reformist and consecutive political dynamics since the outbreak of Qerro's protest against the ruling party prior to the nomination of Prime Minster Dr. Abiy Ahmed.

\section{METHODS}

In this study, qualitative research design was mainly administered. The rationale behind employing qualitative method was that it is imperative to make an interview with politicians entailed in the political scenarios to enquire the underpinnings of parties rift and resulted political dynamics. As a matter of democracy deficit in Ethiopia, most of the political conspiracies are done behind the close door which made qualitative approach relevant for this study. Therefore, key informant interview and case study were used to investigate the situations associated with parties' rift. Data collection were conducted to the information saturation point from diverse primary and secondary sources. Primary data sources like: incumbent politicians, political activists, protesters, opposition members, journalists, foreign diplomats in the country, intellectuals and other significant were reached through purposive sampling design for the data triangulation purpose during the data collection. In addition, secondary data sources like government policies, media analysis and interview records were used to boost the primary data.

In this study, collected data were analyzed through preliminary exploration by reading through the transcripts, listening records, writing memos; using codes to develop themes by aggregating similar codes together and constructing a narration.

Ethical issues were addressed at each phase in this study. An informed consent form that states the participants are guaranteed with the right to agree or disagree to be involved in the study was administered during the data collection. Privacy of the informants was protected. Freedom to share their feelings was insured. All study data were kept confidential in the researchers' office and would be destroyed after a reasonable period of time. 
Shoa: Political Dynamics the Rift of

EPRDF Coalitions Since the Outbreak of

Qerro's Protest to the Nomination of

Dr. Abiy Ahmed in Ethiopia

\section{RESULTS AND DISCUSSIONS}

Political Dynamics Associated with the Rift of EPRDF Coalitions. Qerro's Protest Against Integrated Master Plan of Addis Ababa. Who are the Qerro, and how they have moved to bring one of the Africa's strongest and most autocratic government to its knees, is merely dimly understood (Gardner 2008). There is little information about the Qerro. Their organizational structures are not officially known and their leaders have been mysterious. Nevertheless, they have managed to mobilize a massive amount of people to protest since the broke out of the Oromo's Protest movement in 2014. One scholar expressed Qerro's fierce resistance in such a way that 'young people of Ethiopia have internalized their resistance against the TPLF led EPRDF regime the same way their ancestors did against the Italian occupation of the 1930s' (Freda 2008). One of the immediate factor for the Qerro's movement broke out was “development projects" of Addis Ababa Master Plan. The Master Plan was developed in cooperation between Addis Ababa City Administration and Oromia regional government, led by the then OPDO. The Master plan provoked significant protests in the area affected by it, that is Oromia region. One of the principal concerns of the protest was that the implementation of the master plan would lead to the eviction of millions of Oromo farmers and families from their land. Despite state of emergency was declared after protest erupted in November 2015, the movement continued growing (Ethiopia Human Rights Project, 2016) and finally extended to the ruling party itself. So, Qerro movement was pertinent in that it was a synergetic force behind the birth of reformist actors in OPDO which later became ODP.

Integrated master Plan of Addis Ababa with its surrounding suburbs found surrounding Finfine special zone of Oromia region was alleged to be the key dawn of Qerro's struggle outbreak against the incumbent regime. Government asserted that 'Addis Ababa would be integrated with its surrounding suburbs by infrastructural facilities' without any consultation of the people living in the area. Officially, the political motive behind the master plan was obscure. However, people had smashing suspicion that the intention is to unruly expand Addis Ababa city to Oromia region and thereby sabotage the resources in the region. There was also ambivalence in that the government eventually intends to annex surrounding 
Finfinne towns of Oromia region to Addis Ababa city administration under the shadow of integrated master plan. That means, integrated master plan was seems to be launched to expand geo-political configurations of power in the city governance. That is the epicenter where the protest broke out particularly from Qerro's of Oromo against both regional and federal governments that was operating against the interest of the Oromo people. A lot of people including figurative politicians were jailed, killed and crippled in the course of insurgencies. A case in point is September 2016 massacre at Bishoftu Irecha festival. One survivor of the massacre reported that "2016 Irrecha festival was turned out to protest's ignited by the then political currencies few minutes after the gatherings". Hostile reaction of deployed militaries and polices to the protest vandalized the life of many attendants though it didn't stop the wider movements. Eventually, the movement ensued in the step down of the then Oromia regional authorities and empowerment of the so called "Team Lema" in place that have been working neck and neck with conservative EPRDF coalitions. Soon came to power, "Team Lema" took different reformative actions of which, embracing: Qerro's protest, diaspora factions and entrenching alliance with partners like ADP is worth mentioning. Finally, Qerro protest halted the implementation of Addis Ababa integrated master plan at the cost of causalities. It is following this dynamic that EPRDF vividly exhibited political alignment and internal rifts in to conservative and reformist.

Tactical Alliance of ODP, Former OPDO and ADP, Former ANDM. As evidences reveal, internal forces behind the rift of EPRDF coalitions which perhaps demolished TPLF political hegemony was tactical alliances of ODP (Oromo Democratic Party) and ADP (Amhara Democratic Party), the hitherto titular coalitions. One politician posed that "clandestine chain of TPLF network was drained by the tactical mood of protest created by the so called "team Lema"

that ultimately embraced qerro and diaspora movements". One key informant also stated that: 


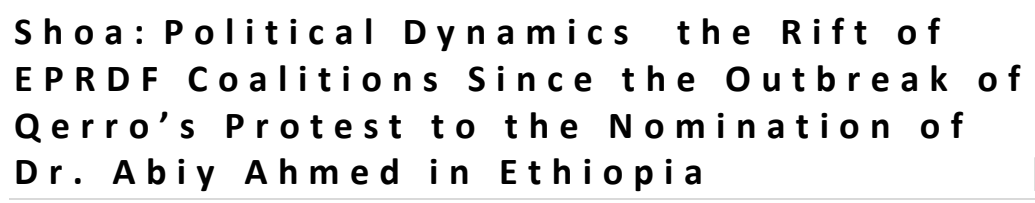

"EPRDF coalitions have faced rift and wider public protests by then. ODP (the then OPDO) was acting as the leading coalition of reformist faction. Top ODP officials created what is anonymously called Team Lema that embraced ADP (the then ANDM), diaspora dissident and mobilized Qerro's movement. TPLF on its side deployed different strategies to suppress the reform among which establishing hidden alliance with the then ESDP authorities was one" (Interview March, 2019).

From the above data one can understand that "Team Lema" was acting as an instigator of internal reformism while conservative coalition, TPLF was vowing for the statuesque on the other alignment. "Team Lema" was acting anonymously by dual responsibility in the course of insurgency against TPLF monopoly. One is, as Oromia regional authorities and the other is, as an internal political activists vowing for the efficacy of written constitution. In this spirit of twofold, the team has got popular and hence embraced some ADP authorities and mobilized youths typically called "Qerro" that was protesting against the maladministration's at both regional and federal levels. Activists and diaspora pressures synergized the movements. Tactical alliance of ODP and ADP solidified synergetic movements against conservative faction, TPLF that polarized the tensions amidst the ruling coalitions and ultimately led to the resignation of late Prime Minister Mr. Hailemariam Desalegn. Finally, unprecedented grievances that lasted for long times diminished the survival of TPLF hegemony. TPLF, EPRDF on its side, deployed different copying strategies such as: apologizing, altering cabinets, declaring state of emergency and creating mysterious alliances with regional authorities like EthioSomali to suppress the protests. However, those measurements couldn't safeguard the conservative incumbent from losing the central monopoly.

Wider Boycott to Weaken the Government. Boycotting business activities were the recurrent measurements undertaken by the protestors to economically bankrupt the incumbent government in the course of insurgencies. Boycotts taken by business firms, farmers, hotel owners, shopping centers and other business organizations were the principal avenues to economically exhaust the ruling party. One respondent stated that "political activists and Qerros took initiatives to organize the boycott by posting different notices tonight informing the people that there 
would not be business activities for certain times with possible sanction on nonconformists'. People were also cooperative in closing business centers that finally augmented the intention of diminishing government economic power. What is astounding was that people used to buy their weekly or biweekly consumption one beforehand and stay at home throughout until the boycott was winded.

\section{Figure 1}

\section{Picture that shows road and business centers boycott}

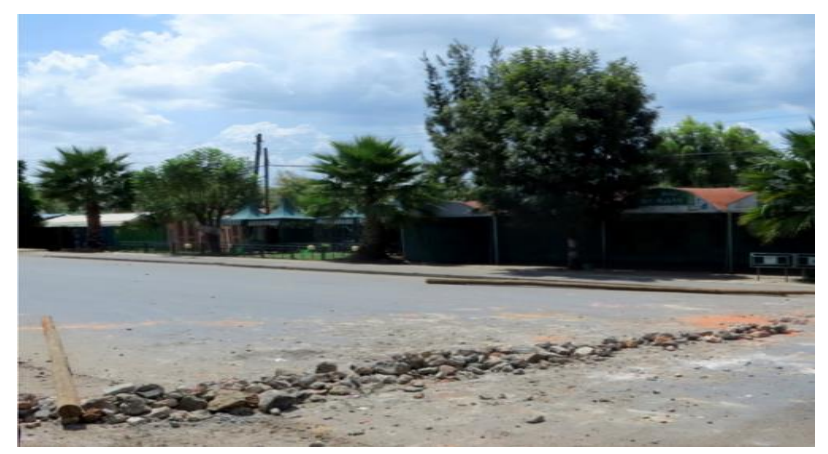

Source: Media Archive

Market boycott was accompanied by transportation ban, student's class boycott and civil servant's absence from the job. With the exception of airlines, it was the time all means of travel banned. People were forced to spend the whole boycott time at home. Busses travelled by then risked the crashes of window glasses and fire damages. Students were also busy with rallies and grievances to attend the classes. They boycotted classes with the precondition to impose sanction on the attendants. Even, some universities have entertained violent demonstrations that resulted in causalities of human life and properties. Civil servant's absence from office was another betrayal received by the ruling party that cumulatively exhausted the economic power of the government. It is important to point out here that the boycott was dependent on the strategy of organizers as it was sudden launching and stays for unknown period of times perhaps a week or more. In this course of boycotts, social media particularly Facebook has played a pivotal role in serving as a platform to share notices and keep people alerted about the scenarios.

From the above paragraphs one can implicate that multifaceted Qerro's protest from within the country that exhausted the ruling incumbent joined diaspora struggles in due course. Diaspora activists ignited the protest by mobilizing more youths in the country and freely posing comments on the strategy of the movements. The ruling party on its side kidnapped a lot of politicians and youths involved in the protests. However, those measurements irreparably speeded up the demise of TPLF 
monopoly. It was following this uncontrollable movement that the incumbent government declared state of emergency (military rule) on March 2017 for the second time in Ethiopia.

Following the failure of government capacity to control the overall instability by the normal administrative structure, state of emergency was declared on March 2017 for the second time in Ethiopia. One politician castigated that "the way state of emergency got verdict by the house of people representative was fraudulent". However, because of democracy deficit by then it was not possible to halt its implementation. As a result, deployed military forces have killed unarmed civilians making peaceful rallies at different places of which the 'death of seven civilians in Chelenko and eleven civilians in Moyale town is worth mentioning'. Government negligently responded that "the death of eleven civilians in Moyale town market area was due to wrong information dispatch to the operating battalion in the area". Therefore, political rivalries among the ruling coalitions coupled with relentless Qerro's protest ensued in central margin shift of political power among the ruling coalitions.

Following the resignation of late Prime Minister Mr. Hailemariam Desalegn, EPRDF has got another bombshell agenda of whom to place in the position. Party congress was held among the four EPRDF coalitions to present their candidates and thereby evaluate the candidate's eligibility for the position. As one participant of the congress stated, 'it was assumed that ODP would present Dr. Abiy Ahmed, ADP, Mr. Demeke Mekonen, TPLF, Dr. Debretsion Gebreigzaber and SPDM, Mr. Shifara Shugute for the sought position. However, ADP exempted itself from presenting any candidate at eleven hours in intention to anonymously give its vote for ODP candidate, Dr. Abiy Ahmed. TPLF on its side played another trick by presenting Dr. Debretsion Gebreegzbiher in intention to give its members vote for SPDM candidate Mr. Shifara shugute'. This is another juncture where they vividly shown the political alignment and coalitions rift in to statuesque and change seekers. Finally, getting the majority vote and winning the game, Dr. Abiy Ahmed, ODP candidate became the prime minister of Ethiopia.

Displacement of Oromo People from Ethio-Somali Region. There have been strong socio-economic and cultural relationships among the Somali and 
Oromo people from the down of history. It is expressed that 'both claim the same lineage backgrounds back to the Kush family' that fosters their sense of sisterhood and brotherhood. Moreover, sharing similar belief system and economic exchanges among the two population on the border areas augment their culture of peaceful interactions. The displacement of Oromo people from Ethio-Somali region however is a fresh outbreak that the then political dynamics bear. One victim of the displacement reported that:

"In Ethio-Somali region, having Oromuma identity would send you to jail. Because Oromuma is often associated with OLF. EthioSomali regional government has a phobia of OLF and its members. It considers OLF as a trait to the region and regime. This slanted government attitude towards OLF and Oromo people is often preached to the Somali people to build distorted image of Oromo's" (Interview March, 2019).

It is demonstrated in the above interview data that Oromo people have been ridiculed in the region because they were often associated with OLF. OLF is assumed potential trait to the region which refers the interest of regional government in defending the regime and thereby contributing to the statuesque. It is indicated that Somali people were "preached" the twofold linkage of being an Oromo and OLF (Oromo liberation front) by the then regional incumbent to politically inject the people that both are adversary to the region. It looks what strong propaganda was made to distort the image of Oromo people among the Somali's through political injection to provoke people on the people. Here, it is bold to sense the political motivation of Ethio-Somali regional government in defending the regime that was in demolishing by the then wider public movements specially Qerro's protest. So, though attempt was made to incline the issue to people to people animosity, it is authenticated that underlying political interest injected to the people takes lion share in uprooting the Oromo's.

Respondents said that good governance was missing in the region because of the fact that government is discriminatory to some ethnic groups living in the region. Though, diverse ethnicities are living in the region the then incumbent officials were asymmetrical to some of them. Government was allegiant to the Somali and few other ethnicities while it was paranoid to some non-Somali ethnic people. Especially, Oromo people were the mostly purged and mistreated people in the region. One victim of the displacement reported that: 


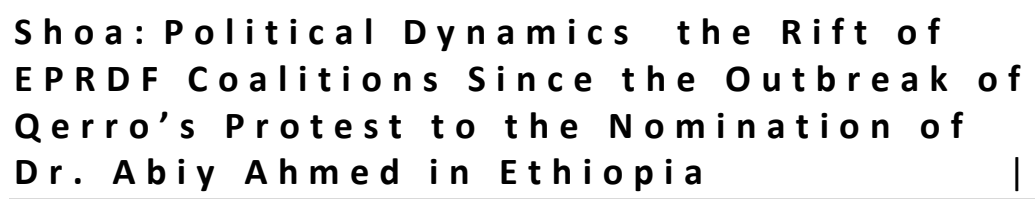

"One day we were summoned by the village manager and he said that Tigrians are our brothers and sisters. They are responsible for the installation of today's federal democratic system. They are the one who liberated us from the harsh political system and gave us todays bright. Hence, they deserve respect. Some others are striving to drain this regime and grip power by force. That is impossible; we will stand with our Tigrian brothers to preserve this system at any cost" (Interview March, 2019).

From the above data one can comprehend that Qerro struggle was considered as a threat to the regime as they were often associated with OLF. When the village manager says "we would fight against forces draining the regime", he is perhaps referring to the Qerroe's protest. The village manager vow to "preserve the regime at any cost" reveals regional government commitment to maintain statuesque with the other conservative coalitions. It is mentioned in the data that "Tigrians are our brothers and sisters". What does this imply? That means, other ethnic groups were not seen in equal eyes for the village manager and perhaps other levels of administrations in the region. So, his/her vow to preserve the regime at any cost could be what he/she emotionally uttered to convey to the people that the regional government would take any action to suppress the protest among which massive displacement of Oromo people could be one. Hence, the regional government was in the scandal of maladministration in that it was asymmetrical to different ethnic peoples living in the region. Thus, one can easily understand the political alliance of perhaps TPLF and ESDP (parties ruling Tigray and Somali region by then) to defend the regime and thereby maintain statuesque. This verifies that the purpose of displacement was to suppress the Qerro's protest.

It is divulged that TPLF, conservative EPRDF coalition has created mysterious alliance with the then Ethio-Somali regional government to challenge the reforms undertaken by the reformist coalitions of EPRDF and Qerro's protest. TPLF is alleged to be the blockages of reform. Qerro movement has broadened the fracture of incumbent regime in to intransigent and change seekers. TPLF applied all possible means to suppress the reformist forces move to drain its political monopoly. Out of that, creating mysterious alliance with Ethio-Somali region government and launching proxy war on the Oromo people living in Ethio-Somali 
region to thereby divert the attention of protesters and Oromia regional authorities were some.

What confirm the political alliance of TPLF and ESDP is the enforcement of Oromo people by the armed groups to leave Ethio-Somali region during displacement. Displaced people witnessed that 'forced displacement was instigated by armed groups deployed by the regional government having mysterious networks with military forces'. The victims reported that 'all atrocities were perpetrated by special forces of the region with high participation of "Hegos", politically missioned and commissioned youths in the region'. The then federal government (TPLF dominated) lackadaisical attention to the case also reaffirms its hidden interest to the political dividend of displacement and atrocities.

Apprehension of Contraband Trade. EPRDF Government authorities have been engaging in contraband businesses using the system operating in their favor particularly before the nomination of Prime Minister Dr. Abiy Ahmed in Ethiopia. One informant responded that:

"Contraband is the lucrative businesses that people engage in in Ethio-Somali region. As the region is close to Wucale, an informal business corridor for the contrabandist, many federal and regional authorities use this route for contraband businesses. This allows corrupted government officials who are striving for the statuesque to dominate the economic realm by purging legal business firms" (Interview March, 2019).

From the above data one can understand that government officials were engaging in contraband businesses that informally enter into the country through Wucale from Somali Land. It was described that Wucale has been serving as an informal business corridor for the politicians engaging in contraband businesses. Political deadlock amidst conservative and reformist group therefore, seems to be for the diverged interest of maintaining dominance in informal business on the one hand, and apprehending contrabandists on the other hand. This implies the presence of conflict of interest on the political economy of the country which perhaps underpins the rift of EPRDF coalitions in to conservative and reformist. Conservative groups dare to retain the dominance of political economy while reformist groups were struggling to break through the statuesque in collaboration with Qerro's protest. Politicians' engagement in the contraband business reveals that economic domain was monopolized by certain groups who were on power in addition to the political hegemony. Hegemony of political and economic sectors, 
the two key means of domination by certain ruling group justifies the why of Qerro's and reformist coalition movement. As a result, deployed polices by reformist group in collaboration with Qerro's apprehended the contrabandists in different areas of Oromia region which retaliatory repercussion from the conservatives ensued in the massive displacement of Oromo's from Ethio-Somali region. As one politician said "within few times of anti-contraband movements, a lot of illegal foreign currencies, illegally imported products, illegal gun sells and others were controlled by integrated efforts of Qerro's and Oromia regional police".

In the above discussion, it is prudence to question why Wucale route was selected by the contrabandists particularly politicians other than others. In unprecedented displacement of Oromo people from Ethio-Somali region it was revealed that ESDP has been in alliance with TPLF in defending statuesque by suppressing Qerro's movement and diverting the attention of reformist coalition. So, political alliance amidst TPLF and ESDP looks the main reason for using Wucale as the strategic contraband corridor by conservative groups. Following the outbreak of Qerro's protest which gave birth to the formation of "team Lema" however, it became hardly possible for the contrabandist to move illegal businesses from Ethio-Somali region through Oromia. Thus, it seems what the conservative groups resorted to uprooting the Oromo's from Ethio-Somali region to suppress the protest and busy the reformist coalition. So, the displacement of Oromo people from Ethio-Somali region seems a repercussion that anti-contraband movement has partly brought.

Release of Political Prisoners. In Ethiopia, politicians have been facing unofficial kidnapping, forced exile and undemocratic treatments in locked up jails as a matter of democracy deficit particularly before the reformism of EPRDF. Reformist faction has been urging for unconditional release of political prisoners though conservative group insisted with allegation of opponents as a terrorist agent operating to destabilize the country. Qerro protestors were also making demonstrations against unlawful kidnapping and towards the release of political opponents in intention of realizing the widening of political spaces in the country. Finally, synergetic push enforced the conservative coalition to admit and allow for the unconditional release of political prisoners. As a result, people sentenced to life 
prison because of their opposing political attitude and action were released and those who stayed in exile returned back home country following the widening of political spaces. Parties in hitherto armed struggle have decided to adjust themselves to peaceful avenues of political struggles. One office incumbent politician stated that "Oromo liberation front and Arbagnoch Ginbot Sebat parties have disarmed their militaries and brought back home from Eretria after agreement on peaceful struggles with the incumbent government". Hence, it is possible to say that Qerro's struggle in collaboration with significant others have played an immense role in laying the ground for today's stage of political reforms in the country.

Post TPLF Lead EPRDF Dynamics. It seems that the issue of nation building is yet unsettled in Ethiopia as the country is surviving under multiple constraints challenging its unity even after the reformism of EPRDF. The country has been under the unitary rule until EPRDF overthrew Derg regime and winded unitary political system. However, as one respondent reported "there are survivor political agents operating towards the restoration of unitary state being on today. In the contrary, federalist forces argue that federalism is a political system that is never subject to bargaining for Ethiopia as the country embraces diverse nation and nationalities". This polarized political interests between the unitary and federalist elites is unfolding among the wider people of different ethnicities which is potentially dividing people and escalating ethnic tensions. Forces vowing for unitary often appeal for the change of EPRDF constitution with the rationale that the constitution is ethnic based down playing individuals citizens right, while federalist forces mainly struggles for its efficacy with the admittance of minor amendment. The political alignment therefore, seems to be between these two political interests: strengthening federalism and restoring unitary since the time of "EPRDF reformism".

Another sensitive dynamic erupted post TPLF lead EPRDF was the melting of EPRDF coalitions under the naming of PP (prosperity party) embracing the three coalitions: ODP, ADP, SPDM and hitherto partner parties. It was only TPLF that secluded itself from PP. Controversial rebuke were being posed towards PP since the party congress was held and endorsed its establishment. One of the dilemmas with PP is whether it is a new establishment or conversion of EPRDF to PP. One politician said that "EPRDF is totally dissolved and new PP is formulated with new 


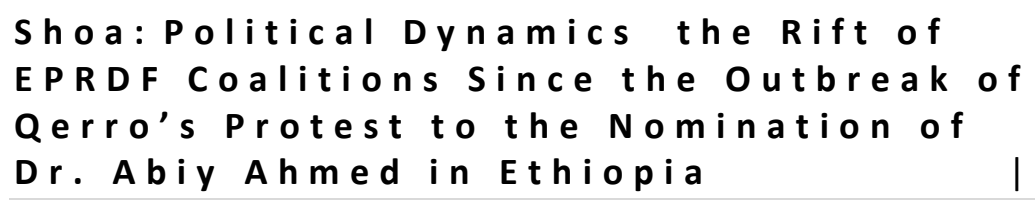

structure, new program, new internal rules and new spirit" while one other respondent reported that "EPRDF realized its long lasted dream of embracing partner parties by switching or melting EPRDF coalitions in to PP'. So, for some it is the turning point old chapter of segregating partner parties was winded. On the other hand, TPLF and other opposition asserts that EPRDF is totally dissolved and the new party is in the process of establishment which is a trait to the federal system and tends towards the centralization of power. PP is also castigated in that its formation is untimely, swift and superficially discussed among the members before the verdict. So, some parties firmly call for the establishment of transitional or interim government until election is held as the party elected to rule the country with its program is already dissolved in order to avoid crisis associated with legitimacy of PP. Therefore, the vanish of EPRDF party particularly, before the election period coupled with the withdrawal of TPLF from PP opened up new dynamics of political alignment which could perhaps result in escalated tensions, state fragility on the one hand, and of course opportunity of inclusion for hitherto partner parties on the other hand.

\section{CONCLUSIONS}

Qerro uprisings have been exhibited since the time of imperial rules in Ethiopia. However, it has been conducted in a piecemeal fashion until "Team Lema" came to power and mobilized them for unity. "Team lema" is the time when Oromo people dissolved back and forth kind of relationship with the regional government and came to somehow the same page on synergistically struggling against the conservative central government. It is since then that the ruling party faced internal fracture and the reformist group swiftly advanced in draining the monopoly of conservative faction. The main issue behind the why of insurgence were: cancelation of integrated master plan of Addis Ababa with the surrounding suburbs of Oromia region; widening of democracy spaces for the political opponents; unconditional release of political prisoners; effectiveness of federalism; autonomy of regional states, efficiency of written constitution and so forth.

TPLF, leading conservative faction, took different measurements to suppress the synergized protests. At first, it admitted maladministration and overall 
scandal it falls in and openly apologized to the people. It also subtly entrenched alliances with partners like ESDP to put proxy pressure for the massive displacement of Oromo people from Ethio-Somali region so that, the attention of reformist faction and protesters would be diverted. Reforming cabinets now and then and deploying polices and militias to shoot on the protesters were another measurement taken by the conservative coalition to suppress the protest. However, some of these measurements backfired and contributed to the demise of TPLF dominance.

The divisions of ruling factions have resulted in broad spectrum of political dynamics in the country. Massive displacement of Oromo people from EthioSomali region for the political dividend calculated by the conservative faction was figurative. Apprehension of contrabandist's who have been freely retailing before that by the reformist group at different places particularly in Oromia region was another bombshell issue ignited the process of reformism. Business firm's market boycott, student's class boycott, civil servants work boycott, transportation ban and other sectorial boycotts were another action taken by the protestors to economically diminish the ruling party in deadlock. Another pertinent dynamic was second time declaration of state of emergency which the wider people deem that its approval was fraudulent. State of emergency was declared at the time of unfolding critical political unrest which was uncontrollable by the normal administrative structure. The resignation of late Prime Minister Mr. Hailemariam Desalegn is also highly harnessed with the failure to control polarized political interests amidst the reformist and conservative factions. Finally, the party held congress that stayed for seventeen days on which agenda of candidates to be placed in the prime Minister position was determined after long lasted contentions. In general, it is possible to draw the conclusion that mobilized and synergized Qerro protest (which is external) have gave birth to the formation of "team lema", leader of reformist coalition that internally challenged the statuesque of TPLF dominated EPRDF rule.

\section{REFERENCES}

Aalen, Lovise. 2006. "Ethnic Federalism and Self-Determination for Nationalities in a Semi- Authoritarian State: The Case of Ethiopia." International Journal on Minority and Group Rights 13:243-61. 


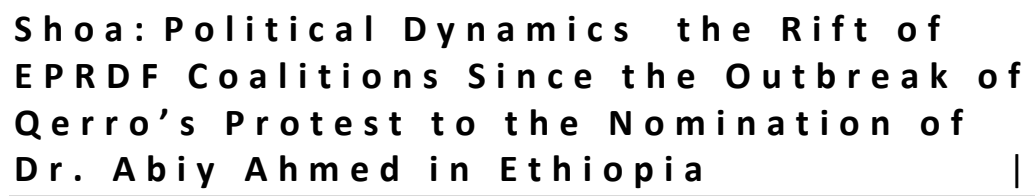

Abbink, J. 2006. "Ethnicity and Conflict Generation in Ethiopia: Some Problems and Prospects of Ethno-Regional Federalism." Journal of Contemporary African Studies 24(3):389-413.

Abbink, J. 2011. "Ethnic-Based Federalism and Ethnicity in Ethiopia: Reassessing the Experiment after 20 Years." Journal of Eastern African Studies 5 (6):596-618.

Adegehe, A. K. 2009. Federalism and Ethnic Conflict in Ethiopia: A Comparative Study of the Somali and Benishangul-Gumuz Regions, Doctoral Thesis, Department of Political Science, Leiden University.

Adem, Teferi Abate. 2004. "Decentralized There, Centralized Here: Local Governance and Paradoxes of Household Autonomy and Control in NorthEast Ethiopia Africa." 4: 612-629.

Adimassu, Y.G. 2015. Implication of Ethiopian Federalism on the Right to Freedom of Movement and Residence: Critical Analysis of the Law and the Practice, Master's Thesis, Addis Ababa University.

Braathen, E., and Hellevik, S. B. 2008. Decentralization, Peacemaking, and Conflict Management: from Regionalism to Municipalism, Journal of Peace, Conflict and Development, 12.

Edmond Keller, J. 2002. "Ethnic Federalism, Fiscal Reform, Development and Democracy in Ethiopia.” African Journal of Political Science 7:1: 21-50.

Freda, N. n.d.“Opinion: Can Ethiopia Overcome Its Crisis and Be a Normal Country? Addis Standard."

Gardner, T. n.d."Freedom! The Mysterious Movement That Brought Ethiopia to a Standstill."

Gizaw, H. 2019. Socio-Political Dynamics Underpinning the Displacement of Oromo People from Ethio-Somali Region and Their Life Trajectories since Displaced the Case of Sebeta and Adama Resettlement Sites.

Gudina, Merera. 2006. Contradictory Interpretations of Ethiopian History: The Need for a New Consensus. In: Ethnic Federalism. The Ethiopian Experience in Comparative Perspective. Turton, David (ed.). Oxford: James Currey.

Lyons, Terrence. 2019. The Puzzles of Ethiopian Politics. lynne Rienner, USA.

Sandra Fullerton Joireman. 1997. Opposition Politics and Ethnicity in Ethiopia: We Will All Go Down Together, The Journal of Modern African Studies, VOL. 
18| The Journal of Society and Media 5(1)

35, NO. 3, pp. 387-407. Printed in the United Kingdom, Cambridge University Press. 